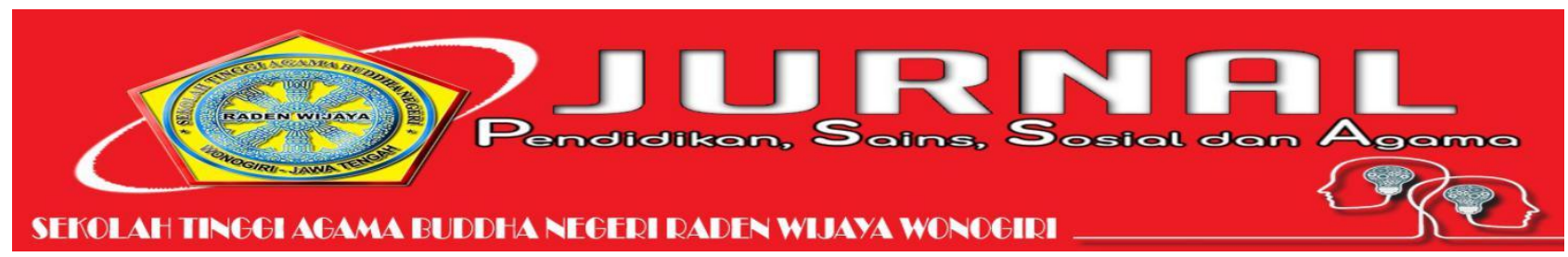

\title{
PENGEMBANGAN MEDIA PEMBELAJARAN E-BOOK BERBASIS PROBLEM SOLVING PADA MATERI SISTEM PENCERNAAN MANUSIA
}

\author{
Umu Istikomah $^{1}$, Mahrawi $^{2}$, Dwi Ratnasari ${ }^{3}$ \\ UNTIRTA \\ 2224170028@untirta.ac.id,mahrawi@untirta.ac.id,dwiratnasari@untirta.ac.id
}

\begin{abstract}
Abstrak
Penelitian ini bertujuan untuk mengembangkan media pembelajaran e-book menggunakan aplikasi Flip pdf profesional berbasis problem solving pada materi sistem pencernaan manusia dan untuk menguji kelayakan media e-book yang dikembangkan melalui validasi para Ahli serta mengetahui kemenarikan respon guru dan peserta didik. Merupakan jenis penelitian pengembangan/ Research and development yang menggunakan model 4D dengan tahapan (define, design, develop and dessiminate) pada penelitian ini hanya sampai tahapan develope. desain penelitian kualitatif deskriptif. e-book sebagai variabel bebas dan sistem pencernaan manusia sebagai variabel terikat. Populasi dalam penelitian adalah 10 siswa-siswi kelas XI SMA AL-khairiyah 4 Cilegon, tahun pelajaran 2021/2022. Teknik pengambilan dan pengumpulan data dilakukan secara penyebaran angket dan wawancara, teknik analisis data dengan menggunakan skala interpretase dan skala likert untuk menguji kelayakan e-book yang sudah dibuat. Hasil penilaian ahli media,diperoleh nilai $82 \%$ dan dan uji ahli materi diperoleh nilai $79 \%$ yang termasuk ke dalam kategori layak sedangkan uji respon uji respon siswa diperoleh nilai 88\%dan dewan guru81\%dengan kategori sangat menarik, berdasarkan hasil penelitian dapat disimpulkan bahwa: e-book sistem pencenaan manusia berbasis problem solving layak untuk digunakan siswa pada materi sistem pembelajaran biologi.
\end{abstract}

Kata kunci: e-book, problem solving, sistem pencernaan manusia, pembelajaran biologi

\begin{abstract}
This study aims to develop e-book learning media using a professional problem-solving-based Flip pdf application on the human digestive system material and to test the feasibility of e-book media developed through expert validation and to find out the attractiveness of teacher and student responses. Is a type of research development / Research and development that uses a 4D model with the stages (define, design, develop and dessiminate) in this study only to the develope stage. descriptive qualitative research design. e-book as independent variable and human digestive system as dependent variable. The population in the study was 10 students of class XI SMA AL-Khairiyah 4 Cilegon, the academic year 2021/2022. Data collection and collection techniques were carried out by distributing questionnaires and interviews, data analysis techniques using an interpretation scale and a Likert scale to test the feasibility of the e-book that had been made. The results of the media expert assessment, obtained a score of $82 \%$ and the material expert test obtained a value of $79 \%$ which is included in the appropriate category while the student response test response test obtained a value of $88 \%$ and the teacher council $81 \%$ based on the results of the study it can be concluded that: e-book system Human digestion based on problem solving is feasible for students to use in biology learning system materials.
\end{abstract}

Keywords: e-book, problem solving, human digestive system, learning biology 


\section{PENDAHULUAN}

Kemajuan teknologi dan tuntutan zaman saat ini, diperlukannya inovasi penunjang proses pembelajaran yang dapat meningkatkan ketercapaian pendidikan di Indonesia, terutama inovasi pada media pembelajaran. Media pembelajaran merupakan segala sesuatu yang dapat mengantarkan message, merangsang pikiran, perasaan, menarik perhatian, dan kemauan peserta didik sehingga mendukung proses belajar (Ardian, 2016). Media pembelajaran yang digunakan oleh guru umumnya adalah media pembelajaran sederhana yang terdapat di lingkungan sekitar (Widodo et al., 2021). Inovasi media pembelajaran sangat diperlukan, karena merupakan komponen penting dalam sebuah pembelajaran, sehingga dapat menjadi sumber acuan materi yang disampaikan oleh guru. Sampai dengan sekarang sudah banyak bermunculan media pembelajaran baik secara cetak maupun elektronik, media pembelajaran yang menunjang kemajuan teknologi dan memudahkan proses pembelajaran, misalnya media pembelajaran $e$-book.

Sebagai jawaban tantangan zaman, penggunaan $e$-book dapat menunjang siswa dalam proses pembelajaran. E-book merupakan media pembelajaran elektronik yang dibuat untuk memudahkan siswa dalam mendapatkan sumber belajar, khususnya di masa pandemi sekarang.Seorang siswa dapat belajar secara praktis dengan $e$-book yang dimilikinya, sifatnya yang elektronik dapat di akses di ponsel maupun di alat elektronik lainnya.E-book disusun dengan media visual dan audio sehingga tidak menyebabkan kejenuhan pada siswa dalam belajar.Sesuai dengan hasil penelitian Ghofur dan Witjaksono (2015), pengembangan $e$-book bagi siswa dinyatakan layak bagi Tim Validator dan praktis untuk digunakan peserta didik.Materi pelajaran biologi merupakan ilmu sains yang dikenal abstrak dan sulit dipahami, serta berkaitan langsung dengan kehidupan sehari-hari. Sehingga pada pembuatann e-book perlu adanya pengembangan media, yang dapat menunjang proses pembelajaran berjalan dengan baik.

Pembelajaran biologi pada materi sistem pencernaan manusia, berkaitan langsung dengan kehidupan sehari-hari, hal tersebut menuntut peserta didik untuk memiliki keterampilan memecahkan masalah.Guna menjadikan siswa yang mampu menjawab tantangan zaman dan turut serta memberi solusi dan berperan di masyarakat atas masalah-masalah yang ada di sekelilingnya yang berkaitan dengan sistem pencernaan.E-book berbasis problem solving disusun berdasarkan contoh-contoh permasalahan di kehidupan sehari-hari siswa, sehingga dapat meningkatkan keterampilan peserta didik, dan menunjang tercapainya tujuan pembelajaran.Ulya et al. (2017) menyatakan, diketahui bahwa model pembelajaran berbasis problem solving jauh lebih baik dan efektif digunakan pada penguasaan materi siswa dibandingkan dengan media berupa modul biasa. Kemudian, sesuai pembelajaran abad 21 Siswa akan dituntut untuk memiliki keterampilan critical thinking and problem solving.

Berdasarkan hasil wawancara analisis kebutuhan di SMA Al-Khairiyah 4 Cilegon sistem pencernaan manusia masuk dalam kategori sedang untuk dipahami dengan presentase kurang lebih $60 \%$, Namun, dalam praktik dan media pembelajaran yang digunakan sangat minim dan kurang memadai, serta adanya rasa kesulitan dari dewan guru untuk menjelaskan materi biologi lainnya, melihat perkembangan teknologi dan keadaan pandemi yang sedang melanda, siswa cenderung belajar melalui media elektronik karena dikenal praktis dan mudah diakses, maka perlu adanya pengembangan media pembelajaran yang menunjang proses belajar peserta didik, pengembangan media pembelajaran e-book belum ada yang melakukan dan belum diterapkan di sekolah SMA Al-Khairiyah 4 Cilegon. Harapannya ada pengembangan media pembelajaran yang dapat memudahkan dan menunjang siswa dalam mendapatkan sumber belajar ucap guru Biologi di SMA Al-Khairiyah 4 Cilegon.

Berdasarkan analisis masalah di atas, dan Untuk mengatasi permasalahan yang terjadi di lapangan.Peneliti bermaksud melaksanakan penelitian pengembangan media pembelajaran dengan dengan judul pengembangan media pembelajaran e-book pada materi sistem pencernaan berbasis problem solving.

\section{METODE}

Penelitian ini dilakukan pada bulan juli 2021 di SMA AL-khairiyah 4 cilegon. Subjek penelitian ini diperoleh berdasarkan sumber data dari 10 siswa/i kelas XI SMA Al- Khairiyah 4 Cilegon, dan subjek penelitian ini adalah siswa siswi kelas XI tingkat SMA yang mengikuti mata pelajaran Sistem Pencernaan Manusia, Teknik pengumpulan data yang digunakan pada 
penelitian ini yaitu dengan pengumpulan dokumen, wawancara dan hasil observasi. Penelitian ini merupakan jenis penelitian dan pengembangan research and development $(R \&$ $D)$.merupakan penelitian yang digunakan untuk menghasilkan produk tertentu dan menguji kelayakan produk tertentu dengan menggunakan model pengembangan 4D (four - D). Terdiri dari 4 tahapan meliputi, define, design, develop, dan dessiminate (Thiagarajan, 1974:5). Desain penelitian pada metode penelitian ini menggunakan Model thiagarajan (4D) yang terdiri dari 4 tahapan yaitu pendefinisian (define), tahap perencanaan (desain), tahap pengembangan (develop) dan disseminate (penyebaran), namun pada penelitian ini dilaksanakan sampai tahapan develop

Instrumen yang digunakan pra penelitian yaitu instrumen berupa kuesioner dan wawancara yang ditujukan kepada peserta didik untuk mengetahui ketertarikan dan kebutuhan peserta didik dalam pembelajaran khususnya pada media pembelajaran e-book dan wawancara kepada pendidik untuk mengetahui kebutuhan dan kesesuaian penggunaan $e$-book pada siswa SMA kelas XI di SMA Al-khairiyah 4 Cilegon, Instrumen pasca penelitian yaitu instrumen validasi materi meliputi aspek kualitas isi materi dan instrumen validasi ahli media terdiri dari aspek desain dan kemudahan dalam penggunaan media yang dikembangkan.

Teknik pengolahan data pada penelitian ini menggunakan teknik analisis deskriptif. Yang memberikan gambaran deskripsi terhadap suatu objek yang diteliti melalui data sampel atau populasi yang ada, pengolahan data yang digunakan dalam bentuk presentase dengan rumus yang digunakan yaitu:

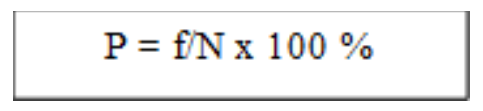

Keterangan:

$$
\begin{aligned}
& \mathrm{P}=\text { Angka persentase } \\
& \mathrm{F}=\text { skor yang diperoleh } \\
& \mathrm{N}=\text { skor maksimal yang diharapkan }
\end{aligned}
$$

Kemudian dilakukan penilaian instrumen oleh validasi ahli media dan ahli materi, menggunakan skala likert, Adapun skala likert yang digunakan yaitu dapat kita lihat pada tabel 3.1 berikut.

\section{Tabel 2.1 Skala likert}

\begin{tabular}{lll}
\hline Kategori & Nilai & Skor \\
\hline SB & Sangat baik & 5 \\
B & Baik & 4 \\
C & Cukup & 3 \\
K & Kurang & 2 \\
SK & Sangat kurang & 1 \\
\hline
\end{tabular}

(Sulistyaningrum, 2017)

\section{A. Hasil validasi ahli materi}

Validasi ahli media dimaksudkan untuk menguji kelayakan dari segi media dari e-book sistem pencernaan manusia yang sudah dibuat, penilaian validator Materi meliputi aspek akurasi materi, cakupan materi, dan aspek kesesuaian dengan tata bahasa dengan rincian penilaian

\begin{tabular}{|c|c|c|c|c|c|}
\hline No & Aspek & $\begin{array}{c}\text { Juml } \\
\text { ah } \\
\text { nilai }\end{array}$ & $\begin{array}{c}\text { Sko } \\
\text { r } \\
\text { ma } \\
\text { x }\end{array}$ & $\%$ & $\begin{array}{l}\text { Kriteri } \\
\text { a }\end{array}$ \\
\hline 1. $\begin{array}{l}\mathrm{ak} \\
\mathrm{m}\end{array}$ & $\begin{array}{l}\text { kurasi } \\
\text { nateri }\end{array}$ & 23 & 30 & $\begin{array}{l}77 \\
\%\end{array}$ & layak \\
\hline 2. $\begin{array}{l}\mathrm{ca} \\
\mathrm{m}\end{array}$ & $\begin{array}{l}\text { akupan } \\
\text { nateri }\end{array}$ & 32 & 40 & $\begin{array}{l}80 \\
\%\end{array}$ & layak \\
\hline $\begin{array}{l}\text { 3. } \mathrm{ke} \\
\text { tat }\end{array}$ & $\begin{array}{l}\text { esesuaian } \\
\text { ata bahasa }\end{array}$ & 24 & 30 & $\begin{array}{l}80 \\
\%\end{array}$ & layak \\
\hline $\begin{array}{c}\text { Jumlah } \\
\text { total }\end{array}$ & 79 & & & & \\
\hline $\begin{array}{c}\text { Skor } \\
\text { maksimal }\end{array}$ & 100 & & & & \\
\hline $\begin{array}{c}\text { Presentase } \\
\text { Kriteria }\end{array}$ & $\begin{array}{l}79 \% \\
\text { Layak }\end{array}$ & & & & \\
\hline
\end{tabular}
sebagai berikut:

Tabel 3.1 Penilaian validator ahli Materi

Skala interpretase uji ahli materi:

$$
\begin{aligned}
\mathrm{P} & : 79 / 100 \times 100 \% \\
& : 0,79 \times 100 \% \\
& : 79 \%
\end{aligned}
$$

Berdasarkan tabel 3.1 didapatkan nilai untuk setiap aspek yaitu aspek akurasi materi dengan presentase $77 \%$ dengan kriteria layak, aspek cakupan materi $80 \%$ dengan kriteria layak dan aspek kesesuaian dengan tata bahasa dengan nilai $80 \%$ dengan kriteria layak. Adapun penyajian hasil validasi media dijabarkan melalui grafik sebagai berikut: 
Gambar 3.2 Grafik Hasil Validator Materi

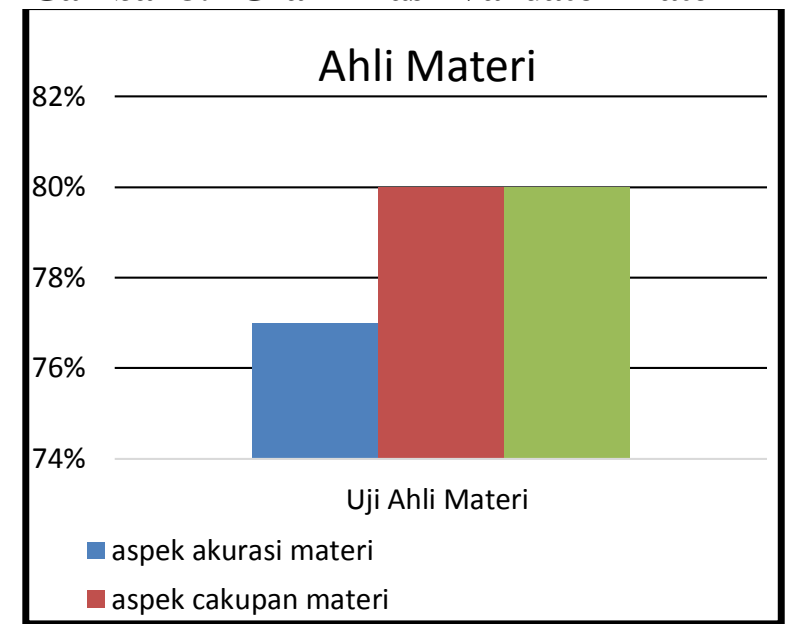

Dari gambar 3.2 diketahui media e-book sistem pencernan manusia dari segi materi dan aspek yang dinilai memenuhi kriteria layak.Sehingga dapat diujikan kepada siswa dengan saran harus diperbaiki terlebih dahulu $e$-book nya sesuai saran perbaikan yang disampaikan validator.

\section{B. Hasil validasi ahli media}

Validasi ahli media dimaksudkan untuk menguji kelayakan dari segi media dari e-book sistem pencernaan manusia yang sudah dibuat, penilaian validator media meliputi aspek desain, aspek problem solving, dan aspek karakteristik $e$ book dengan rincian penilaian sebagai berikut:

\section{Tabel 3.3 Penilaian validator ahli media}

\begin{tabular}{|c|c|c|c|c|c|}
\hline No & Aspek & $\begin{array}{l}\text { Juml } \\
\text { ah } \\
\text { nilai }\end{array}$ & $\begin{array}{l}\text { Sk } \\
\text { or } \\
\text { ma } \\
\mathrm{X}\end{array}$ & $\%$ & Kriteria \\
\hline 1 . & Desain & 37 & 45 & $\begin{array}{l}82 \\
\%\end{array}$ & $\begin{array}{l}\text { Sangat } \\
\text { layak }\end{array}$ \\
\hline 2. & $\begin{array}{l}\text { proble } \\
\text { m } \\
\text { solving }\end{array}$ & 17 & 20 & $\begin{array}{l}85 \\
\%\end{array}$ & $\begin{array}{l}\text { Sangat } \\
\text { layak }\end{array}$ \\
\hline 3. & $\begin{array}{l}\text { karakter } \\
\text { istik e- } \\
\text { book }\end{array}$ & 28 & 35 & $\begin{array}{l}80 \\
\%\end{array}$ & layak \\
\hline \multirow{2}{*}{\multicolumn{2}{|c|}{$\begin{array}{l}\text { Jumlah total } \\
\text { Skor } \\
\text { maksimal }\end{array}$}} & \\
\hline & & 100 & & & \\
\hline \multicolumn{2}{|c|}{ Presentase } & \multicolumn{4}{|l|}{$82 \%$} \\
\hline \multicolumn{2}{|c|}{ Kriteria } & \multicolumn{4}{|c|}{ Sangat layak } \\
\hline
\end{tabular}

Skala interpretase uji ahli materi:

Asosiasi Dosen \& Unit Penelitian dan Pengabdian Masyarakat

$$
\begin{aligned}
\mathrm{P} & : 82 / 100 \times 100 \% \\
& : 0,82 \times 100 \% \\
& : 82 \%
\end{aligned}
$$

Berdasarkan tabel 3.3 didapatkan nilai untuk setiap aspek yaitu aspek desain dengan presentase 82\% dengan kriteria sangat layak, aspek problem solving $85 \%$ dengan kriteria sangat layak dan aspek karakteristik e-book dengan nilai $80 \%$ dengan kriteria layak. Adapun penyajian hasil validasi media dijabarkan melalui grafik sebagai berikut:

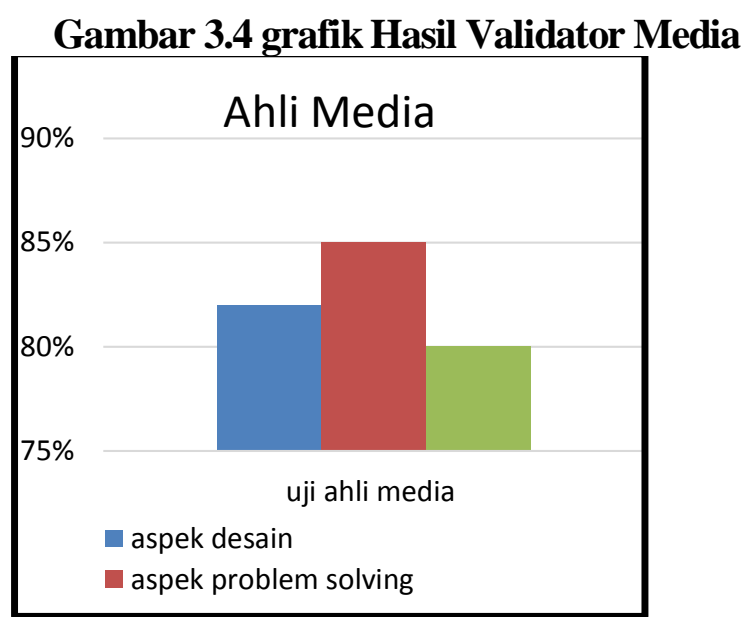

Dari gambar 3.4 diketahui media e-book sistem pencernan manusia dari segi media dan aspek yang di nilai memenuhi kriteria layak.Sehingga dapat diujikan kepada siswa dengan saran harus diperbaiki terlebih dahulu $e$-book nya sesuai saran perbaikan yang disampaikan validator.

\section{Uji Respon Guru Biologi dan Siswa}

Uji respon guru biologi dan siswa dimaksudkan untuk mengetahui respon dari guru biologi dan siswa tentang e-book yang sudah dibuat, berdasarkan angket hasil uji respon guru biologi didapatkan nilai $81 \%$ dengan kriteria menarik dan uji respo siswa dari 18 orang siswa kelas XI didapatkan presentase $88 \%$, dengan perhitungan sebagai berikut.

Skala interpretase uji respon siswa:

$$
\begin{aligned}
\mathrm{P} & : 1105 / 70 \times 100 \% \\
& : 1579 / 18 \text { Orang } \\
& : 88 \%
\end{aligned}
$$

Skala interpretase uji guru biologi:

Dari gambar perhitungan interpretase di atas,

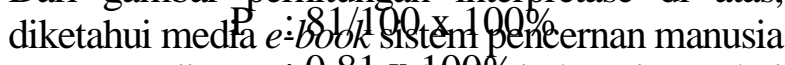
menurut uji responp, \&lux blÖOgi dan siswa dari
$: 81 \%$ 
aspek yang di nilai, memenuhi kriteria sangat menarik.

\section{KESIMPULAN}

Berdasarkan uji ahli media diperoleh nilai $82 \%$ yang termasuk kategori layak dan dan uji ahli materi diperoleh nilai $79 \%$ yang termasuk ke dalam kategori layak, selanjutnya berdasarkan uji respon guru biologi diperoleh nilai $81 \%$ dengan kriteria menarik, dan uji respon siswa dengannilai 88\% dan diketahui bahwa e-book sistem pencernaan manusia yang dibuat menarik, berdasarkan data yang diperoleh dapat disimpulkan bahwa e-book sistem penecranaan manusia berbasis problem solving layak untuk digunakan pada proses pembelajaran biologi di sekolah, dan menarik sehingga dapat membantu siswa dalam mengembangkan sikapproblem solver.

\section{UCAPAN TERIMAKASIH}

Ucapan syukur kehadirat allah, yang maha Rahman akhirnya Peneliti dapat penyelesaian skripsi ini, kepada kedua orangtua, yang tak pernah berhenti berdoa dan membantu dan ucapan syukur kepada pihakpihak yang telah memberikan motivasi baik moril maupun materil, tidak lupa pula peneliti menyampaikan terima kasih dan penghargaan kepada:

1. Bapak Prof. Dr. Ir. H. Fatah Sulaiman, ST., MT sebagai Rektor Universitas Sultan Ageng Tirtayasa Banten.

2. Bapak Dr. Dase Erwin Juansah., S.Pd., M.Pd sebagai Dekan Fakultas Dekan Fakultas Keguruan dan Ilmu Pendidikan Universitas Sultan Ageng Tirtayasa Banten.

3. Ibu Mila Ermila Hendriyani, S.Si., M.Pd Sebagai Ketua Jurusan Pendidikan Biologi dan Ibu Dr. Iing Dwi Lestari, M.Si selaku Sekretaris Jurusan Pendidikan BiologiFakultas Keguruan dan Ilmu Pendidikan Universitas Sultan Ageng Tirtayasa Banten.

4. Bapak Mahrawi, M.Pd selaku Dosen Pembimbing I dan Ibu Dwi Ratnasari, M,Pdselaku dosen pembimbing II yang telah meluangkan waktunya dan mencurahkan pemikirannya demi pengarahkan penulis dalam menyelesaikan skripsi ini.

5. Kepala Sekolah SMA AL-khairiyah 4 Cilegon dan Guru Mata Pelajaran Biologi
SMA AL-khairiyah 4 Cilegon yang telah memberikan izin untuk mengadakan riset penelitian dan memberikan kemudahan kepada penulis untuk memperoleh data di lapangan.

6. teman-teman seperjuangan, mahasiswa jurusan pendidikan biologi angkatan 2017 yang selalu menyemangati dan berjalan beriringan.

Akhirnya semoga Allah SWT berkenan membalas segala kebaikan dan amal semua pihak yang telah membantu.Semoga skripsi ini bermanfaat bagi pengembangan ilmu pengetahuan.Amin Ya Robbal Alamin.

\section{DAFTAR PUSTAKA}

1. Book:

Arsyad, A. (2010). Media Pembelajaran. Jakarta: PT Rajawali Press.

Edra.R. (2017).Bagaimana Organ Pencernaan Manusia

Bekerja?Diakses dari Bagaimana Organ Pencernaan Manusia Bekerja? IPA Kelas 7 (ruangguru.com)19 Maret 2021, pk.10.20

Junqeira, L.C. \& Jose Carneiro (1980).Basic histology. California: Lange Medical Publications.

Lowther, E. Deborah Lrussel, james D. (2014). Instructional ttechnology \&media for learning (teknologi pembelajaran dan media untuk belajar).Palangkaraya. Kencana Prenada Media Group.

Maulidiya.A. (2018).Berpikir dan Problem Solving. Sekolah tinggi agama islam raudhatul akmal (STAIRA). Ihyaul Arobiyah. 6 (40).

Muhadi, Y (2012). Media Pembelajaran. Jakarta: Gaung Persada Press

Polya, G. (1981). How to Solve It. New Jersey Princenton: Princenton University Press

Steel \& Glassgow dalam Arsyad (2011).Media Pembelajaran.

Jakarta: Raja Grafindo Persada

Thiagarajan, Sivasailam, Dorothy, S. Semmel, \& Melvyn, L. (1974).Instructional Development for Training Teachers of Exceptional Children. Bloomington, Indiana: Indiana 
Wahyu, P. (2009). Sistem pencernaan pada manusia. Bandung: PT. Sarana Ilmu Pustaka.

Yusnimar.(2014). E-Book Dan Pengguna Perpustakaan Perhuruan Tinggi di Jakarta. Maktabah 13, (1), 34-39.

2. Journal:

Alwan, M. (2018).Pengembangan Multimedia E-Book 3D Berbasis Mobile Learning Untuk Mata Pelajaran Geografi SMA Guna Mendukung Pembelajaran Jarak Jauh.Jurnal At-Tadbir STAI Darul Kamal NW Kembang Kerang I, (2), 29.

Ardian, A. \& helda, S. (2016) pengembangan media pembelajaran berupa bulletin dalam bentuk buku saku untuk pembelajaran ipa terpadu. Jurnal ilmiah pendidikan fisika al-biruni. 5, (1), 3

Ghofur, A. \& R. Kustijono. (2015). Pengembangan e-book berbasis flash kvisoft flipbook pada materi kinematika gerak lurus sebagai sarana belajar siswa sma kelas $x$. Jurnal inovasi pendidikan fisika (jipf), 04 (02), 176-180.

Kurniawan, O \& noviama E. (2013).Penerapan kurikulum 2013 dalam meningkatkan keterampilan sikap, dan pengetahuan.Jurnal primary program studi pendidikan sekolah dasar FKIP UNRI.6 (2), 390.

Mentari, (2018).Pengembangan media pembelajaran e-book.PENDIPA Journal of science education, 2 (2), 131-134.

Prabowo, A. \& Heriyanto.(2013). Analisis Pemanfaatan Buku Elektronik (EBook) oleh Pemustaka di Perpustakaan SMA Negeri 1 Semarang. Jurnal Ilmu Perpustakaan. 2 (2), 1-9

Rasiman.\& P. Sari. (2014). "Development of mathematics learning media Ecomic based on flip book maker to increase the critical thingking skill and character of junior high school students". International journal of education and research, 2 (11), 1-2.
Ratnaningdyah. (2017). Upaya melatihkan kemampuan pemecahan masalah melalui pembelajaran fisika dengan model cooperative problem solving(cps). Jurnal ilmu pendidikan fisika, 2 (1), 2.

Sulistyaningrum, D.A. (2017). Pengembangan quantum teaching berbasis video pembelajaran Camtasia pada materi permukaan bumi dan cuaca. Jurnal profesi pendidikan dasar, 2(4), 154-166

Ulya, H. \& Efkar, T. (2017). Pengembangan Modul Kimia Berbasis Problem solving Pada Materi Asam Basa Arrhenius. Jurnal Penddidikan Dan Pembelajaran Kimia, 7 (1), 129141.

Kurniawan.D, dewi.S.V. (2017). Pengembangan perangkat pembelajaran dengan media screenscast-0-matic mata kuliah kalkulus 2 menggunakan model 4D. Thiagarajan. Jurnal siliwangi, 3, (1), 216-217

Widodo, U., Ngadat, \& Subandi, A. (2021). Designing Interactive Audio-Visual Instructional Media Based On Value Clarification Technique ( VCT ). Journal of Education Technology, 5(4), 611-618. https://doi.org/10.23887/jet.v5i4.40412 